\title{
Research on the Education Pattern and Optimization Countermeasures for Contemporary College Student Ideological and Political Education under the Internet Background
}

\author{
Jiaqian Zhang \\ Department of Social Sciences, Binzhou Polytechnic, \\ Shandong,256600, China
}

\begin{abstract}
In this paper, we conduct theoretical research on education pattern and related optimization countermeasures for contemporary college student ideological and political education under Internet background. College students' ideological and political education main body collaborative system its function is restricted by the structure of the system. In order to better play to the core function of the system, and therefore should be studied in the college students' ideological and political education main body, on the basis of collaborative system structure, system optimization according to the actual situation in a timely manner, to establish a coordinated system structure, the elements of building the best "match", play to the ideological and political education main body the overall educating function of collaborative system. Starting from this perspective, our research proposes the novel paradigm for the education with Internet that holds special meaning.
\end{abstract}

Keywords- Education Pattern, Countermeasures, College Student, Ideological, Internet.

\section{Introduction}

Mode of ideological and political education in higher vocational colleges is to point to in under the guidance of the scientific education theory, in the long-term practice of the ideological and political education, on the basis of the basic characteristics of higher vocational colleges and actual situation, optimization and combination of various basic methods and form a relatively stable structure and supporting the implementation of strategy is a fixed orientation of ideological and political education of systematic and theoretical paradigm [1-3].
Based on related research results, the research status of ideological and political education essence can be roughly classified into two categories, namely "social standard" and "individual standard". The analysis and grasp the essence of the ideological and political education is a gap on the basis of the personal thought personal character and social requirement, in the process of practice, by perfecting social demands and personal thought personal character, personal and social benign interaction and organic unity. That is to say, the starting point of the ideological and political education is the social requirements and the gap between individual ideology and moral character. This gap is characterized by individual thought personal character divide in the social requirements, performance requirements for the society divide in personal ideology and moral character, as well as the basic approach between them. According to the constituent elements of ideological and political education process, this paper argues that the college students' ideological and political education can try coordinated from the main body, content, carrier to explore collaborative dimensions such as basic effectiveness. Contemporary college students' ideological and political education is a holistic concept, the idea of domination of the student education, should focus on students' ideological and moral quality of integrity to pay attention to the comprehensive schools in various educational resources [4-5].

Nowadays, with the high speed of social informatization, network with its unique way, penetrating into every area of society. The application and popularization of the network for 
students has opened up a new study, the road to success as also change the ideological work environment, will affect the students' outlook on life, values, world view, to the college ideological education as has brought the good opportunity, at the same time also brought new and grave challenges. Network in addition to is a kind of phenomenon of single technology, but more show its social commonality, is a kind of social cultural phenomenon. Large amount of information in network, wide coverage, spread rapidly, so by college students in acquiring knowledge and information. Access network popularization and college students growing rapidly, to strengthen and improve college ideological education work to provide a good opportunity. In the figure one, we demonstrate the principles.

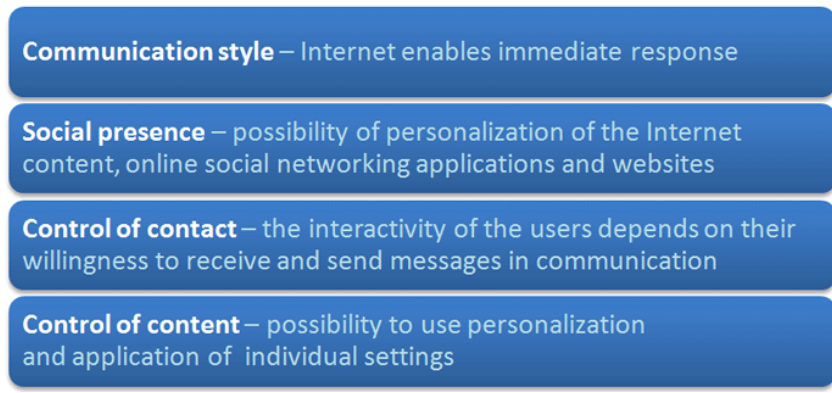

Figure 1. The General Features and

Characteristics of the Internet

In this paper, we conduct theoretical research on the education pattern and the related optimization countermeasures for contemporary college student ideological and political education under Internet background. Network environment for the university ideological education work as has brought new opportunities and severe challenges. The traditional teaching methods and the teaching ideas and the optimal out, instead of the more advanced open concept of the moral education, therefore, ideological educators to improve the effect of political education under the network environment, open up a new situation of ideological work. In the later sections, we will discuss the issues in detail.

\section{The Proposed Methodology}

The Characteristics of Education Reform. Teaching reform is system engineering as is inner link and law of organic unity. Personnel training mode, course system, teaching content, method, means and support conditions such as the integration of the elements of optimization which is the inevitable requirement of deepening teaching reform and the development trend and is to overcome the single course, individual level or the limitations of the single teaching reform and the important measure to improve the effect of the overall educational reform [6].

System integration thoughts should be consistently throughout all the teaching process that mainly reflected in the combination of classroom teaching and the social teaching, the integration of theory teaching and practice teaching, the content of the organic unity of the educational reform of teaching and learning which could be separated into the listed aspects. (1) Functional integration. Functional integration refers to the first in the teaching process to improve the quality of imparting knowledge, ability cultivation and the integration of basic diversified teaching goal. The teaching process is the scientific spirit and humanistic spirit, unity of knowledge education and quality-oriented education, imparting knowledge is not a pure science and applied. To carry out the quality education, the most fundamental is to put the quality education thought through education activities and various teaching link always. (2) Methods to integrate. Different characteristics of the teaching content should adopt different teaching methods single teaching method is not adapt to the diversification of the teaching object demand and the diversity of core teaching goals. Methods integration is a series of teaching characteristics of a variety of teaching methods of the organic link. (3) Link and process integration. Teaching link and process integration is refers to the teachers' teaching and students' learning of each link in the process of the integration. The relationship between teachers and students is not 
a simple relationship between teaching and learning, but the interactive relationship between teachers and students, and so the teachers and students and mutual trust relationship.

The Internet and the Education. Network convenience to college students' study and life, and provides students with the world advanced culture and fully demonstrate the space of the individual talent, but also the ideological understanding, value concept and behavior caused great impact. In the new environment, ideological and political education workers to adapt to the situation development, found the problem in time, the innovation education teaching method, exploring the way the age of the Internet for the ideological and political education of college students, to ensure the actual effect of ideological and political education work. Due to the development of information network, break through the limit of space and the time information transmission, so as to realize the rapid flow of information around the world; All manner of websites are struck with its powerful lineup people all aspects of the work, life and learning, sparked the thread type big wave of reform, education industry has also been a serious challenge, therefore, faces enormous change.

\begin{tabular}{l|l|l} 
Feature & \multicolumn{1}{|c}{ Web 1.0 } & \multicolumn{1}{c}{ Web 2.0 } \\
\hline $\begin{array}{l}\text { Metaphor for the } \\
\text { Internet }\end{array}$ & Information superhighway & Platform for interaction \\
\hline $\begin{array}{l}\text { Metaphor for the } \\
\text { WWW }\end{array}$ & $\begin{array}{l}\text { Web of information resources stored on a } \\
\text { global network of servers where what } \\
\text { matters is retrieval and display }\end{array}$ & $\begin{array}{l}\text { Human web where what matters is } \\
\text { human contacts and relations } \\
\text { between individuals }\end{array}$ \\
\hline Major sites & Information portals & Online social networks \\
\hline Tools & $\begin{array}{l}\text { Oriented to display and retrieve information } \\
\text { stored on the Internet }\end{array}$ & $\begin{array}{l}\text { Designed to enable collaboration and } \\
\text { content creation on the Internet }\end{array}$ \\
\hline Strategy pursued & Efficiency & Effectiveness \\
\hline Economies sought & Economies of scale & Network effects \\
\hline Software used & Software as a product & Software as a service \\
\hline Computing model & Client-server & Cloud computing \\
\hline $\begin{array}{l}\text { Communication } \\
\text { range }\end{array}$ & Wide and local area networks & $\begin{array}{l}\text { Mobile communication also } \\
\text { considered }\end{array}$ \\
\hline Issues & Technological & Social
\end{tabular}

Figure 2. The Developmental Trend of the Web Forms

As shown above, the general web forms are illustrated. For the systematic description of Internet based education platform, we can organize it as the follows. (1) Cloud operating system. The cloud operating system supports cloud application flexible deployment environment, adopt the mainstream distributed computing application server, database system and storage system, to ensure stable and efficient information services are available to the user. (2) Business support platform. Mainly for data integration and integration, the unification of the user identity management and authentication, based on virtual community interaction and general collaborative environment support, the massive content management and service, the interface of the upper application service and the management support, build and deployment of third party applications that provide support for mobile intelligent terminal access, etc. (3)
Education cloud service center. Interactive services including cloud based services and education resources, down through the interface call distributed storage system and cloud storage devices, up to provide education resource service interface for upper application realize the education resources and control of efficient, speaking, reading and writing. (4) Education management center. In meet the national, provincial, city and the county, the school management needs of the business at the same time, through the cloud foundation platform of the data between applications, process, service, satisfy the correlation between different businesses and realize the coordination [7-8].

The Internet Ideological and Political. Colleges and universities thought political lesson if from definition to define, from theory to theory, is both boring and abstract, often not easily accepted by the students. Education courses 
emphasize specific aim, to solve the problem of college students in the course of their growth theory, practical problems, which requires it to understand the structure of the education object, emphasizes pertinence as reflects theory combined with practice, while construction of campus culture is the best carrier to realize the goal of ideological and political education.

Ideological and political theory course in colleges and universities bear the important task of the ideological and moral education for college students, to help college students under the basic guide of scientific theory set up the correct world outlook, the outlook on life, values, ethics, and coordination. However, with the rising popularity of the Internet on college campuses, all kinds of the new thoughts, new ideas all affect the behavior and value orientation of college students, how to reform ideological and the political theory course teaching under the new situation, occupied the position of the network education to improve the pertinence and effectiveness of education courses teaching as has become a problem to research and solve. New media as a new communication form that has the spread of the diversification, personalization, interactive, quickness, characteristics of extensiveness and globality, openness, richness, quickly got recognized and accepted, the college students become the preferred way, they learn to accept information profoundly affects their ideological consciousness and behavior. So in the new media environment, ideological education workers should careful analysis of the new media influence on general university students' thought and behavior, understanding of ideological and political education work is facing new changes and new challenges, changing ideas, advancing with the times, innovation education new method and means, how to improve the pertinence and the effectiveness of the ideological and political education work. Only thinking of new media on campus, that is, the structures and the basic connection between teachers and students of media network is not emphasized the value of network platform itself, but rather to focus on improving the attractiveness of the platform to the teachers and students, the value of this platform by ultimately meet the need for information to reflect the teachers and the students. When platform become "new ecosystem", many teachers and students gathered in the media platform, platform has unprecedented communication, education, etc. New media is the platform on a number of plug-ins, according to the need for plug-ins trade-offs, and then carries on the ideological education or spreading.

The Future of Ideological and Political Education. At present, the mode of ideological and the political education in higher vocational colleges, from specific training goal of the higher vocational college, according to the requirement of the times development, combined with the development of higher vocational characteristics and needs, earnestly study and establish scientific mode of moral education in higher vocational colleges as is not only the country to put forward the task of innovation education system in higher vocational colleges, and puts forward the realistic subject of education career itself. Therefore, we must to the traditional moral education ideas, views and guidelines to the comprehensive summary and reflection for creative transformation.

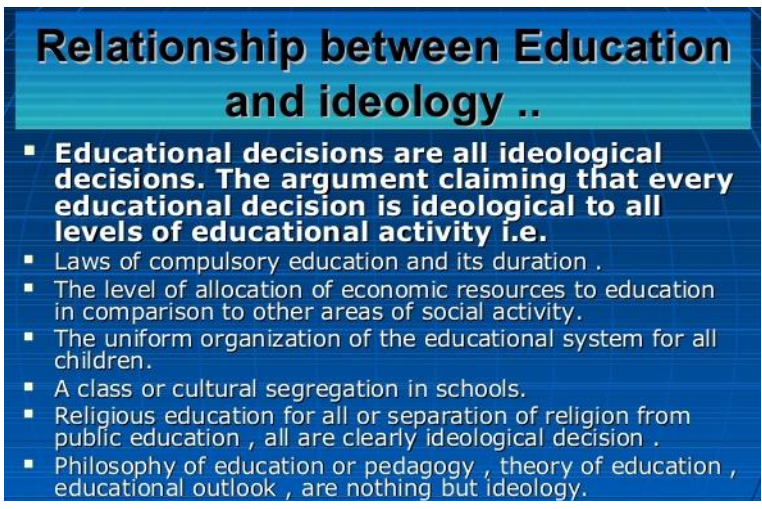

Figure 3. The Future Direction of the Ideological and Political Education 
As adjusting thought relationship between individual and society a kind of the practice activity, the basic rule of ideological and the political education has its own activity. Modern education theory, as a kind of the mental factor is the man's thought cannot be directly measured, but as a reflection of the outside world, man's thought is through its external behavior in everyday life. In real life, effective ideological and political education, to change people's thinking, in turn, affect the person's behavior, therefore, by comparing the educatees in ideological and the political education before and after the manifestation of thought or behavior can determine the effectiveness of the ideological and political education effect. To carry out the ideological and political education effectiveness evaluation not only has realistic feasibility, also has very important practical significance. On the one hand, the traditional ideological and political education evaluation lack of scientific judgment only dimly ideological and political education "valid" or "invalid", not to the ideological and political education in the process of implementation of the specific link for objective analysis, nor for ideological and political education of input and output of precise measurement, therefore, through the effectiveness evaluation is helpful to fully understand the operation process of the ideological and political education, to strengthen the effect of the ideological and political education. Through feedback, on the other hand, the ideological and political education results that also helps to enhance the pertinence of ideological and political education to strengthen the effect of the ideological and political education.

\section{Conclusion}

In this paper, we conduct theoretical research on the education pattern and the related optimization countermeasures for contemporary college student ideological and political education under Internet background. College students' ideological and political education main body structure of the general collaborative system optimization between on the one hand, refers to the ideological and political education main body in the education target, education content, education method of organic, mix, in order to make sure the students ideological and political education on the process of integrity and the continuity, the class of the ideological and political education and daily ideological and political education the layered progressive, as effective connection. On the other hand refers to according to improve the quality, optimized structure, the requirements of the relatively stable construction of the ideological and the political education team. Under this guidance, our research proposes the novel and innovative perspective on the education pattern that will be meaningful.

\section{References}

[1] Wu, Jun, Quan Wen, and Yang Wan. "Research on the Applications of Information and Internet Technology in the Ideological and Political Education of College Students." (2015).

[2] Li, Cai. "On the Construction of New Modes for the Ideological and Political Work of College Students in the New Media Times." The Science Education Article Collects 6 (2014): 008.

[3] Hui, J. I. "Humanistic Care and the Actual Effect of Ideological and Political Education of Colleges and Universities." Journal of Wuyi University 3 (2013): 025.

[4] Yue, D. O. N. G. "Study on Improvement of Teaching Attraction of Ideological and Political Theory Course." Journal of Liaoning Provincial College of Communications 4 (2014): 024.

[5] SONG, Zhen-hua, and Xian-yin PAN. "The Exploration and Practice for Students' Ideological and Political Education in 
University Residence." Journal of Yunnan Agricultural University (Social Science) 2 (2012): 018.

[6] Lingling, He. "On the Ideological and Political Education of University Students from the Perspective of Career Planning." The Science Education Article Collects 2 (2015): 011.
[7] Yue, Bao. "211 undergraduate college students volunteer service under the vision of ideological and political education work." Journal of Jiamusi Vocational Institute 3 (2015): 070.

[8] Jian, Wang. "On How to Integrate Life Education into Ideological and Political Education." Journal of College Advisor 3 (2014): 013. 